\title{
Literopintar Cabo Verde: a criação de autoria feminina
}

\author{
Simone Caputo Gomes*
}

RESUMO: A literatura de autoria feminina retrata Cabo Verde (lê, pinta, desenha, esculpe, escreve), suas belas paisagens, seu cotidiano popular, seus perfis de mulher, sua riqueza cultural.

ABSTRACT: The literature of feminine authorship portraits Cape Verd (reads, paints, draws, engraves, writes), its beautiful landscapes, its popular quotidian, its profiles of women, its cultural richness.

PALAVRAS-CHAVE: Cabo Verde; literatura de autoria feminina; cultura crioula.

KEYWORDS: Cape Verd; literature of feminine authorship; creole culture.

\section{-Primeira sala da exposição: “...De como elas se entregaram aos dias”1}

Cabo Verde sofre hoje a conhecida problemática saheliana do continente africano, caracterizada por longos períodos de seca e pelos problemas da desertificação e da erosão agravada pela ação humana. Esta condição de "Sahel em pleno mar" expõe as ilhas a um clima tropical seco e semi-árido que implica o pouco desenvolvimento dos solos (10\% aráveis) também em virtude da origem geológica recente, vulcânica, do relevo muito acidentado, do fraco nível pluviométrico e da ação dos ventos. Tais fatores repercutem na escassa produção agrícola em um país essencialmente rural, no fraco estado nutricional das comunidades e na emigração da população deste "mundo saariano" para buscar melhores condições de vida. O aspecto arquipelágico de orografia difícil e dispersão bastante acentuada ${ }^{2}$ concorre para o isolamento, que leva ao seu oposto complementar: a mobilidade excessiva.

\footnotetext{
* Profa. Doutora de Literaturas Africanas de Língua Portuguesa, Universidade de S. Paulo, site Amar Cabo Verde: WWW.simonecaputogomes.com. Contato: simonecaputog@usp.br.

${ }_{2}^{1} \overline{\text { Dez (10) ilhas, entre as quais o acesso se faz preferivelmente por avião em virtude }}$ das grandes distâncias, e 8 ilhéus.
} 
Sabemos que, em Cabo Verde, fatores econômicos, sociais, culturais e a emigração masculina impactam diretamente a fragilidade da família, com conseqüente instabilidade da mulher e dos filhos menores. Cerca de $60 \%$ da população crioula é feminina, sendo $33,5 \%$ constituída por famílias chefiadas por mulheres. Por conseguinte, o investimento na promoção da condição feminina tem efeitos multiplicadores que se estendem da família à nação.

Os dados do último Censo indicam que a maioria das famílias cabo-verdianas habita as zonas rurais (em proporção de 2:1 com relação às zonas urbanas), particularmente tocadas pela pobreza, apresentando ainda baixo nível de instrução, escolarização e formação profissional. Cerca de $80 \%$ dos filhos nascem fora do casamento e, em $14 \%$ das famílias, a mãe solteira sustenta a casa e a família numerosa.. Nas zonas rurais, $62 \%$ dos chefes de família são mulheres e $51 \%$ das mulheres conduzem explorações agrícolas; as demais são assalariadas nas cooperativas, no comércio e nas Frentes de Alta Intensidade de Mão de Obra (FAIMO), onde chegam a representar $60 \%$ em domínios como florestação e conservação de solos e águas.

No que concerne à Educação, do total de analfabetos, a mulher representa cerca de $64 \%$ e, das mulheres chefes de família, $62,5 \%$ não têm qualquer instrução. O nível de escolarização impacta fortemente a variável natalidade, havendo uma diferença de 4 (quatro) entre o número de filhos das mulheres menos instruídas e mais instruídas.

Quanto à estrutura demográfica, Cabo Verde apresenta, segundo o último Censo, uma tendência para o equilíbrio dos sexos, ou seja, à nascença há uma proporcionalidade entre os sexos. Mas a situação de vantagem do homem em relação à mulher na sociedade crioula é patente, derivada das referências ideológicas e dos valores cultivados num passado histórico e num ordenamento jurídico não muito distantes, que impunham a superioridade masculina.

Ao aderir em novembro de 1979 à Convenção sobre a Eliminação de Todas as Formas de Discriminação em Relação às Mulheres (CEDAW), Cabo Verde acolheu no seu ordenamento jurídico um dos instrumentos necessários para a materialização de sua política de assegurar que as mulheres tenham direito ao mesmo tratamento dispensado aos homens, já que sempre estiveram presentes, participaram e lutaram juntamente com eles para o nascimento e consolidação do país.

A evolução da condição feminina crioula acompanhou a trajetória históricopolítica em Cabo Verde. Em passos rápidos, caminhemos com ela. 
Num primeiro momento, em virtude das questões coloniais, a mulher era impedida de extravasar o limite do trabalho doméstico, cabendo ao homem o poder de decisão na gestão do lar e na educação dos filhos.

Com a emigração em massa proveniente do declínio das condições de vida no Arquipélago, na ausência do homem a mulher obrigava-se a ser chefe, gestora da economia familiar e representante dos negócios do marido (inclusive poupança e aplicação das remessas oriundas da emigração).

Num terceiro momento, decorrente do seu bom desempenho nas tarefas mencionadas, a mulher passou a acumular tarefas e papéis que ultrapassavam a condição de mulher-mãe, lançando-se de forma mais efetiva no espaço público.

Atualmente, já encontramos em Cabo Verde mulheres trabalhando na estiva, na construção civil, nas forças de segurança pública, na venda de água em chafarizes, na produção agrícola, na pecuária, nos trabalhos em estradas _ redutos considerados anteriormente como exclusivamente masculinos _ lado a lado ao desempenho de serviços de doméstica, servente (97\% de mulheres nas FAIMO), vendedora de pescado ou de hortícolas, cabeleireira, costureira, bordadeira, doceira, considerados tradicionalmente como trabalhos femininos. Nos setores da indústria de confecções, de calçados, extrativa e de conserva de peixes a mulher representa o maior volume de mãode-obra, apesar da importância reduzida dessas indústrias no PIB (11\%). Quanto a cargos de decisão, a presença da mulher ressalta nas atividades de serviços (comércio, hotelaria, restauração), indústria extrativa, serviços sociais e coletivos.

A trajetória política de Cabo Verde fornece-nos também subsídios importantes para destacar as ações afirmativas no que diz respeito às conquistas da mulher nos campos social, político e jurídico.

Na Primeira República (de 1975 a 1990), a Organização das Mulheres de Cabo Verde (OMCV), criada em 1981 com base nos princípios políticos do PAICV e composta por mulheres que participaram no processo de luta pela independência de Cabo Verde, contribuiu decisivamente com suas intervenções para que o processo de igualdade se refletisse nas áreas da sobrevivência, saúde, educação, economia, informação e formação. Hoje constitui uma organização não-governamental, que insiste na sensibilização da sociedade crioula para que valorize o papel da mulher no processo de desenvolvimento.

Na Segunda República, após a abertura política e realização das eleições pluripartidárias (1991) vencidas pelo MPD (Movimento Para a Democracia), atribui-se 
à mulher maior protagonismo ao incrementar políticas especialmente dirigidas a ela no III Plano Nacional de Desenvolvimento: maior integração das mulheres no processo de modernização da agricultura; desenvolvimento do emprego feminino e das cooperativas de mulheres; acesso ao crédito e criação de projetos de desenvolvimento para mulheres; adaptação da escola às condições socioeconômicas das mães; desenvolvimento do ensino pré-escolar como um direito da criança e forma de libertar as mães para o trabalho fora do lar; representação equilibrada nos órgãos legislativos e de decisão.

Com a abertura política, inúmeras associações foram criadas pela sociedade crioula para discutir a problemática da mulher cabo-verdiana, dentre as quais se destacam a MORABI (Associação de Apoio à Auto-Promoção da Mulher no Desenvolvimento, 1991) e a Associação das Mulheres Empresárias (1992).

Em 1994 foi criado o Instituto da Condição Feminina (ICF), com a finalidade de integrar efetivamente a mulher em todos os domínios da vida social, econômica, política e no desenvolvimento auto-sustentado do país.

Em 1995, Cabo Verde participou da Conferência Mundial de Beijing e adotou a Declaração e o Plano de Ação Mundial para as Mulheres. A partir daquele evento, o Governo de Cabo Verde traçou como objetivos: prevenção para reduzir a maternidade precoce e a paternidade irresponsável; aumento dos rendimentos das famílias chefiadas por mulheres; aumento da atenção da sociedade cabo-verdiana à problemática da condição feminina.

O Plano de Ação Nacional das Mulheres (1996-2000) definiu como áreas prioritárias: reforço da capacidade institucional; desenvolvimento rural e da pesca; educação, formação e emprego; saúde e direitos reprodutivos; a mulher e a informação/comunicação; a mulher e a emigração.

O Plano Nacional de Desenvolvimento 1997-2000 propôs ações para eliminar os obstáculos jurídicos, econômicos e sociais a uma participação ativa da mulher caboverdiana nos espaços público e privado, através de uma estratégia que residia nas relações de gênero, concorrente para conduzir progressivamente a uma parceria entre homens e mulheres. A aprovação da lei que estabeleceu a fixação de cotas para mulheres nos partidos políticos e o programa de incentivo às iniciativas do empresariado jovem, prevendo bonificação maior quando no capital social das candidaturas apresentadas a maioria fosse detida por mulheres, são bons exemplos da eficiência daquelas ações. 
O Plano Nacional de Luta contra a Pobreza, elegendo a mulher como destinatário privilegiado, destaca os seguintes eixos: promoção da integração das mulheres pobres nos circuitos econômicos; reforço da capacidade da mulher em desenvolver microempresas e atividades geradoras de rendimento, através da formação e informação; promoção do acesso da mulher aos meios produtivos e a outros recursos pelo microcrédito; ações para melhorar a competitividade da mulher e das jovens, em especial, no mercado de trabalho, através de adequada educação e formação profissional.

Mesmo com todas essas conquistas, subsistem social e culturalmente diversas formas de limitação que impedem à mulher a cidadania plena. O labor doméstico não é incluído nas estatísticas nacionais como força de trabalho, assim como a agricultura doméstica produzida não é contabilizada no PIB. A violência familiar é outro obstáculo e a persistência da prostituição, do turismo sexual e do tráfico de mulheres agrava o quadro da violência na sociedade cabo-verdiana, sendo a coação sexual muitas vezes praticada em casa, ocasionando um índice elevado de homicídios e ofensas corporais graves aos companheiros, praticados por mulheres constantemente espancadas. Maternidade precoce, aborto clandestino, filhos sem pai, alcoolismo e até loucura são algumas conseqüências cerceadoras da emancipação feminina abstraídas do contexto psicossocial que envolve a mulher crioula.

A Literatura não poderia estar alheia às mutações históricas.

Centramos a nossa pesquisa na Escritura de Autoria Feminina em Cabo Verde partindo do pressuposto que ela objetiva, sobretudo, dar visibilidade e voz à historicidade das mulheres. Desenha, à luz da história das mentalidades e da história do social, uma história de olhares situados ${ }^{3}$ e concebe a construção do objeto a partir da politização do lugar de enunciação, preocupando-se em traçar uma história cultural dos espaços e identidades femininas, bem como das modalidades de relações entre os sexos sociais. Estas relações não partem de critérios de exclusão, mas de inclusão, acolhendo as novas masculinidades possíveis em tempos de alargamento das esferas de ação da mulher, que conquista cada vez mais o espaço público. Cabe ressaltar, pois, que a identidade de gênero define-se na experiência compartilhada.

${ }^{3}$ Marcados por lugares como gênero, raça, classe, etnia, orientação sexual, geografia etc. 
Observemos como os textos literários femininos recortam e escrevem a nação Cabo Verde, à luz da síntese contextual apresentada no início deste trabalho com o intuito de facilitar o caminho do leitor não-iniciado nos estudos crioulos.

\section{- Segunda sala da exposição: A Mulher lê e escreve Cabo Verde}

Imagens que reconheço mas que a câmara não captou como eu vi, como vejo ainda. Outro olhar. (...) Eu, a mulher, questionando os papéis que a sociedade me impõe (Sara Almeida) ${ }^{4}$

Investigar a escritura literária de autoria feminina em Cabo Verde supõe compreender em que solo sociocultural as iniciativas se fundam: "As noções de linguagem feminina ou mesmo de identidade feminina, enquanto construções sociais, exigem a avaliação das condições particulares e dos contextos sociais e históricos em que foram estruturadas" (HOLLANDA, Heloísa Buarque de (org).1994, p.14).

Lembramos que a pesquisa histórica feminista, para dar conta das subjetividades plurais emergentes, lança mão de uma hermenêutica do cotidiano $^{5}$, que procura documentar e analisar aspectos concretos da vida dos seres humanos em sociedade. Desta forma, a historiografia feminista tem o caminho metodológico aberto para a possibilidade de construção das diferenças e de explorar a diversidade dos papéis informais. A emergência do privado e do cotidiano na cena dos estudos históricos permite mostrar-se com toda força a presença dos "segmentos subalternos" e das mulheres e os deslocamentos produzidos pelo feminismo têm propiciado a assunção de novos temas e perfis ${ }^{6}$ que contam as experiências das mulheres e que nos permitem reconhecer a origem de crenças e práticas sociais que as estigmatizam.

Em nossa investigação temos detectado um mosaico de olhares femininos sobre a realidade das ilhas - expressos na poesia ou em prosa - , assumindo a temporalidade histórica do tema e tentando acompanhar a escritura literária na apreensão do ser através da experiência vivida, do cotidiano em transformação.

\footnotetext{
4 ALMEIDA, Sara. (1993). P 63 e 23. Montagem.

5 DIAS, Maria Odila Leite da Silva. (1994).

${ }^{6}$ Novos temas da produção historiográfica e outros perfis femininos vão ser tratados e aprofundados: a louca, a bêbada, a drogada, a lésbica, a celibatária, a altiva, a vencedora, ao lado de perfis tradicionais como a avó, a mãe, a filha, a prostituta etc.
} 
A escritura literária de autoria feminina em Cabo Verde tem procurado empreender a viagem ao espaço crioulo, notadamente aos "mundos" habitados e criados pela mulher, que têm por base a casa como metáfora nuclear, a imersão no privado $^{7}$ e no pessoal.

Antónia Gertrudes Pusich (S. Nicolau, 1805-1883), referida por Manuel Ferreira como um dos primeiros autores africanos lusófonos a publicar e alcançar prestígio nos meios literários (lisboetas), começa a compor a galeria de escritoras que vai mudar o "rosto" do cânone cabo-verdiano, marcadamente masculino. Maria Luísa de Sena Barcelos (ou Africana) e Gertrudes Ferreira Lima (Humilde Camponesa) são poetas que com ela participam no Almanach de Lembranças Luso-brasileiro (1851-1932). Sílvia Crato Monteiro e Yolanda Morazzo (1928) vão dando maior visibilidade à produção feminina, com sua colaboração no Suplemento Cultural. Morazzo, pelos anos 60, canta a terra caboverdiana (S. Vicente), diversificando posteriormente a ambiência do seu discurso com a radicação em Angola.

Mais próximas de nós, algumas com tímidas tentativas na Revista Mujer (da OMCV), outras com textos antologiados em Canto liberto (1981) e Mirabilis: de veias ao sol (1991) ou com livro próprio, Alice Wahnon Ferro (1940, S. Vicente), Alícia Borges (1966, S. Vicente), Ana Julia Monteiro de Macedo Sança (1947, Santiago), Arcília Barreto (1945, S. Vicente), Dina Salústio (Bernardina Oliveira, 1941, Santo Antão), Eleana Lima (1965, S. Vicente), Eunice Borges, Lara Araújo (ou Madalena Tavares, 1951, Sal), Lídia do Rosário (1961, S. Nicolau), Luísa Chantre (1964, Sal), MG’Nela (Helena Regina R. M Teófilo, 1959, S. Vicente), Manuela Fonseca, Margarida Moreira, Maria Guilhermina, Maria José da Cunha (Ilha Brava), Maria Lídia do Rosário (1961, S. Nicolau), Nely (1964, Santo Antão), Paula Martins (1957, Santiago) e Vera Duarte (1952, S. Vicente) dão continuidade à tarefa de construir um discurso poético feminino em Cabo Verde.

Em prosa, transitando por vários gêneros _ conto, crônica, romance, novela, ensaio _, a escritura literária de autoria feminina segue um "projeto" claramente vinculado às vivências do cotidiano cabo-verdiano (vidas vividas), retratando-o em

\footnotetext{
7 Em Cabo Verde, a prática da matança do porco alegoriza a relação da mulher com o privado/intimo, enquanto delimita o lugar ocupado por cada gênero no cotidiano. $\mathrm{O}$ homem amarra, sangra, chamusca, raspa, abre e desmancha o animal (tarefas secas e externas, de fora de casa). A mulher apara o sangue, separa as carnes, prepara-as para conservação, derrete o toucinho, lava as tripas, confecciona os enchidos, tarefas (de dentro de casa) associadas às partes úmidas e internas do porco.
} 
diversos níveis: regional, nacional, na diáspora e/ou lançando-se para o universal, sob o crivo da história ou da memória.

Adelaide Maria das Neves (Santiago?), colaboradora do Almanach de Lembranças Luso-brasileiro, com o relato Num baile; Maria Helena Spencer (1911, Praia), com textos sobre a experiência cotidiana da mestiçagem e da emigração no periódico Cabo Verde: Boletim de Propaganda e Informação; Leopoldina Barreto (1937, S. Nicolau, escultora, pintora), com os romances Monte Gordo, 1997, as Vitimas do Amor Impossível, em 2004, e a narrativa A Ilha do Rei Titão (literatura infantojuvenil), em 2000; Rosa de Saron, colaboradora de Fragmentos e Artiletra; Haydeia Avelino Pires (Praia, 1942), publicando contos no Boletim Cabo Verde, 1961; Camila Mont-Rond (pseudônimo de Ondina Ferreira, que nasceu no mar, a bordo do paquete português “Guiné”, em viagem de Mindelo para Lisboa, 1946.), com a coletânea de contos Amor na Ilha e outras paragens, 2001, são algumas produtoras de prosa literária que começam a ter projeção, ainda com pouca fortuna crítica.

Maria Margarida Mascarenhas (1938, S. Vicente) figura em Sèló, Cabo Verde e Presença Crioula, e apresenta a mulher e as relações familiares, tanto no espaço insular (de seca e fome) quanto na diáspora. Seu livro ... levedando a ilha, precedido de um Testemunho da Autora ("EU contista me confesso"), propõe a leitura dos contos "como percurso biográfico (...) onde se entrevê o enquadramento sócio-cultural do livro" (MASCARENHAS, 1988, p.7) e destaca uma personagem: o Povo cabo-verdiano. Processos e temas são à partida revelados ao leitor: a proximidade entre narração e poesia, entre a tradição do conto oral e a narrativa escrita; a identificação da contista com os retratos de Toia, Conceição, de muitas vozes sufocadas ou libertas, vozes de cada ilha levedando a ILHA (Cabo Verde).

Orlanda Amarílis (1924, Santiago), correlacionada ao grupo de Certeza, presenteia o leitor com três antologias de contos (Cais-do-Sodré té Salamansa, 1974, Ilhéu dos Pássaros, 1982, A casa dos mastros, 1989), em que sobressai a literatura de migrante-mulher, repartida entre o espaço lisboeta (representado pelo Cais-do-Sodré) e a terra-mãe (representada por Salamansa), ou dividida entre ficar no Mindelo e debandar para S. Tomé ou para a América, Portugal, França, Suíça. Das mais 
antologiadas e estudadas escritoras africanas, Orlanda é uma contadora de causos, sobretudo por vozes femininas ${ }^{8}$.

Continuando o percurso da prosa em voz de mulher, Ivone Aída (Santiago, 1926) dá título ao volume Vidas vividas a partir do mote: "E um ror de velhinhas desfilando/ Olhares tristes, mãos estendidas/ Que vidas mal vividas!" (RAMOS, 1990, p.59. Grifos meus). Nha Joana, com o canhoto na boca desdentada, e Nha Chica encabeçam o séquito de velhinhas que esmolam pela cachupinha de todos os dias.

Fátima Bettencourt (1938, Santo Antão), em Semear em pó: contos, também constrói as narrativas a partir da presença feminina, colocando-a sempre em relação com personagens-chave do círculo familiar ou do mundo crioulo. $\mathrm{O}$ fio condutor centrase na menina ou adolescente que narra, compondo um vitral de fragmentos de recordações, "quadros vivos" em que a figura da mãe domina o universo familiar ${ }^{9}$ e se expande para comunidade: "Oh menininha de Deus, tua mãe é uma santa (...) tomou conta da escola, tomou conta de todos nós desta ribeira e já não sabemos passar sem ela" (BETTENCOURT, 1994, p 16).

O título da obra, amplo, pode aludir ao trabalho agrícola (a sementeira, trabalho de Sísifo na terra seca, heroísmo de um povo que precisa inventar a água todos os dias), às tarefas ligadas à tecelagem, em que as mulheres separam, cardam, fiam a lã ${ }^{10}$, confundindo-se com a sua poeira; à tecedura do texto, contado ou escrito, ou à transmissão das estórias de geração a geração.

Além de retratar personagens, Fátima é uma virtuose na pintura de cenas, como poderemos adiante observar no relevo que daremos às Cenas apresentadas em Um certo olhar (Crónicas, 2001). Mar Caminho Adubado de Esperança, contos, 2006, e Lugar de Suor, Pão e Alegria, crônicas, 2008, são obras que acrescentam temas e fashes do cotidiano crioulo à galeria exposta pela escritora.

A obra de Dina Salústio (nascida em 1941, na ilha de Santo Antão; Mornas eram as noites, 1994, contos, e A louca de Serrano, romance, 1998) faz coro com a de Fátima Bettencourt quanto aos procedimentos de resgate da cultura tradicional e do exame

\footnotetext{
${ }^{8}$ A obra de Orlanda Amarílis oferece-nos um verdadeiro desfile de narradoras e personagens femininas: Andresa, Nina, Nha Concha, Titina, Bia Sena, Mam Zabêl, Linda, de Cais-do-Sodré té Salamansa; Nh'Ana, Piedade, Luísa filha de Nica, Luna Cohen, prima Bibinha, Nha Rosa, Mam Bia, Xanda, Nha Leocádia, Bina, de Ilhéu dos pássaros; Violete, Laura, Tosca, Maira da Luz, de A casa dos Mastros.

${ }^{9}$ Em Cabo Verde, a família constitui o centro de interesse da vida cotidiana e sua estrutura gira em torno da mãe. À mulher cabe o papel de guardiã dos espaços familiares.

10 Escalonadas por tarefas e experiência. Quanto mais velha a artífice, maior o seu prestígio.
} 
agudo das chagas sociais; seus contos, que condensam a trama em curta-metragem, reiteram a associação da prosa com o poético ao dar relevo à morna, modalidade musical típica de Cabo Verde, que veicula a poesia oral. Revisitando a chamada "morna preliminar" tradicional, canto de mulheres em solo e coro, Dina permitirá ao leitor traduzir o título do livro Mornas eram as noites como "música eram as noites". Música de mulheres, em que a mulher é a principal construtora da nacionalidade e da identidade no cotidiano crioulo. A epígrafe da obra ressalta o fio que a autora quer dar às suas estórias: "...De como elas se entregaram aos dias."

Dina Salústio, um dos olhares mais contundentes sobre Cabo Verde transposto para a linguagem literária, dá relevo ao seu foco: "mulheres cabo-verdianas que trabalham duro, que fazem o trabalho da pedra, que carregam água, que trabalham a terra, que têm a obrigação de cuidar dos filhos, de acender o lume. Quis prestar uma homenagem a esta mulher...". 11

E, a partir deste foco, questiona o lugar do homem (o machismo) e da mulher na sociedade crioula, expondo obstáculos à emancipação feminina (a maternidade precoce, a bebedeira, a loucura) e a necessidade de uma "cumplicidade fêmea" que possibilite a conscientização compartilhada.

Como sintetiza Benjamin Abdala Jr: “À identidade da nação soma-se a do assim chamado gênero. Não se trata apenas de representar Cabo Verde, mas de construir a maneira de ser das mulheres cabo-verdianas" (ABDALA JR., 1999, p.16).

Sara Almeida, em Depois telefono (novela), também faz a sua opção de recorte da realidade: "Se eu quero conhecer o meu país, devo identificar o maior grupo a que pertenço - as mulheres" (ALMEIDA, 1993, p. 79).

Fátima Bettencourt complementa, facultando-nos suas estratégias:

Os textos da presente compilação são de génese vária (...) uns nasceram da observação directa da vida, por vias travessas, havendo ainda os que vieram directos da alma, de alguma dor profunda ou alegria banal, simples ditos ouvidos ao passar de imponderáveis acasos, instantes apenas suspensos do nada, leves toques de ternura ou de beleza, pensamentos fugazes que me levaram a uma compreensão maior da nossa vida, do nosso sentir, das nossas mágoas e esperanças, e o riso, algum, logrei descobrir no fundo da indignação que é, na maior parte dos casos, a alavanca da pena que humildemente venho manuseando (BETTENCOURT, 2001, Prefácio, p. 13).

11 Entrevista concedida a Simone Caputo Gomes, 12 de novembro de 1994, Praia, Cabo Verde. 
E Vera Duarte (Poesia: Amanhã amadrugada, 1993; O arquipélago da Paixão, 2001; Preces e súplicas ou os cânticos da desesperança, 2005; Romance: A candidata, 2005; Reflexões sobre os Direitos Humanos: Construindo a Utopia , 2008) define uma das funções precípuas da escritura feminina:

E como é linda esta folha de papel que nervosamente vou cobrindo de pequenas formas arredondadas que talvez morram no caixote de lixo mais próximo ou levem ao próximo milénio a mensagem do milénio mil, rica e sinuosa, vermelha como um grito, injusta e sombria, mas, acima de tudo, MULHER (DUARTE, 1993, p. 37).

Enfim, as escritoras colocam em ação, em seus textos, a mulher cabo-verdiana, seja como protagonista, coadjuvante ou figurante de destaque, documentando a historicidade da participação feminina na construção e no desenvolvimento do país. A fim de que o leitor possa captar a perspectiva desses olhares femininos sobre o cotidiano crioulo, selecionei painéis, cenas e instantâneos que considero antológicos na composição de um coro de "vozes da margem", organizando-os com o apoio de técnicas das artes plásticas. As autoras/artistas, por meio da magia da técnica literária, pintam verdadeiros retratos do cotidiano crioulo sob uma ótica feminina, objetivando destacar com maior concretude traços comuns e identitários. Encontram uma outra maneira de ler e escrever Cabo Verde e as "vidas vividas” pelas mulheres que constróem a nação.

\section{- Sala principal da exposição: Literopintar(literogravar) Cabo Verde - Galeria de Vozes e Cenas}

- Flash-prelúdio: A Origem e a Identidade (Fátima Bettencourt, óleo pontilhado sobre tela)

Não me canso de meditar na estória, certamente inventada por algum crioulo folgazão e sparajóde, que explica o nascimento das Ilhas do nosso Arquipélago: estaria o Criador em pleno acto de feitura do mundo quando, vencido pelo cansaço e pelo sono, teria deixado cair a pena com que se entretinha esboçando o que viriam a ser os montes, árvores, rios, elefantes, baleias, porcos e galinhas. Da caneta descuidada saltaram alguns pingos de tinta que surpreenderam o Pai Celeste, ao despertar, pois julgava ter retocado tudo havia já um bom tempo.

12 SALÙSTIO, Dina. fragmento de romance inédito. 
Sorrindo porém com ironia e um pouco de malícia murmurou para os divinos botões: 'Deixa lá, não me lembro de ter colocado aí esses pontinhos mas se estão ali, vão ficar. Serão as ilhas de Cabo Verde'. (...) Ele como ser supremo é que não podia jamais dar o braço a torcer e admitir que os tais pingos espalhados no mar eram obra do acaso.

Do acaso nascemos, por acaso fomos achados e não me admiraria nada que fosse obra do acaso o vovô branco ter botado o olho na vovó negra para gerar o mestiço mais inquieto e satisfeito, vaidoso e ingénuo que habita este planeta.

Até quando vamos nós continuar por aí perdidos à procura duma identidade? Até quando nos sentiremos divididos, um pé no nosso cantinho, um pé no resto do mundo? (BETTENCOURT, 2001, p. 327-328)

\section{- Painel: A(s) Ilha(s)-Mãe \\ Cena 1: Santo Antão (Dina Salústio, díptico, acrílica sobre tela)}

Sou de Santo Antão. Vais encontrar em todos os contos Santo Antão. (...) É que a ilha está em mim.(...) É como se todas as ilhas de Cabo Verde fossem Santo Antão. (...) É uma ilha muito poderosa, possessiva. É a ilha a que vou quando preciso encontrar algumas coisas (SALÚSTIO, Dina. Entrevista a Simone Caputo Gomes, 1994.)

A ilha era apenas ela, no sentido inicial da concepção: intocada e intocável. (...) Ameaças, desafios, armaduras, sereias, gongons, veleiros, temporais e calmarias e o Mar do Canal, ainda eram partes do corpo da ilha mãe... (SALÚSTIO, 1994, p. 21)

\section{Cena 2: São Vicente (Fátima Bettencourt, aquarela sobre papel)}

Mindelo vai a pouco e pouco tornando-se um estado de espírito. Baixa uma paz sobre mim quando piso este chão e ando pelas ruas, parando metro a metro, para um abraço, uma conversa amável, às vezes um alô apenas. É a minha cidade que me abre os braços e o coração e me sinto no colo mesmo da minha mãe, acalentada e confortada, em perfeita comunhão com todos e comigo mesma.

Filha adoptiva, é como se tivesse dado coices nas suas entranhas, tenho uma dívida impagável para com esta cidade, esta ilha, estes montes pelados, esta gente indómita.

Eu sei que ela está paradona, estagnada, morta, mas as suas tardes continuam cálidas, as suas noites plenas de magia, e aquele toque de morabeza permanece intacto nas suas gentes que, às vezes, se levantam sem saber se verão o sol baixar no Monte Cara antes de pôrem uma panela de-riba-de-lume. O cati-cati de cada dia, sempre difícil, mas não a ponto de perderem o riso bom, o requebro do andar, a piada inesperada, o dito picante, a graça infinita. (...)

Bela amante adormecida(...) Quem semeará teus bairros de lares-oficinas, escolas-empresas e abrigará teus velhos, teus loucos, teus meninos sózinhos, teus artistas, tuas prostitutas ainda com a boneca escondida no travesseiro? (BETTENCOURT, 2001, p. 49-51)

\section{Cena 3: Fogo (Fátima Bettencourt, carvão e sangüínea sobre papel)}

Chego à Ilha do Fogo depois de 4 anos. Quanta coisa aconteceu, entretanto, quanto sofrimento.(...) Subo a Chã das Caldeiras com um sentimento misto de temor e espanto perante o cenário apocalíptico que nos provoca um nó na garganta ao mesmo tempo que nos sentimos ínfimos seres vulneráveis frente aos mistérios da natureza. Nem uma palavra. Fico ali muda e contemplo apenas 
a grandeza do cataclismo que atingiu aquele lugar e a força da própria natureza na tentativa de superar as perdas e fazer vencer a vida. Maior do que isso só a coragem das gentes da Ilha voltando às suas tarefas, preparando as enxadas e as sementes, lançando-as à terra e vendo a chuva fazê-las crescer em beleza e promessa de sustento. Uma explosão vulcânica são sete anos de fartura _ diz o povo da Ilha em tom desafiador como quem não se importa de pagar o preço (Ibidem, p. 269-270).

Cena 4: O Arquipélago e uma visão da insularidade (homenagem a Jorge Barbosa por Dina Salústio, guache sobre papel cartão)

(...) o cabo-verdiano, ele próprio, (que) só se compreende na insularidade. (...) o mar enorme e sem fim, ditando o rumo, traçando rotas, revelando distâncias, marcando o silêncio, (...) cheiros do mar que o isola do resto do mundo. (...) A insularidade que me faz medrosa, insegura e frágil e que traz consigo essa saudade, companheira dos ilhéus, limitados pelos mares, pelos medos e pelos mitos; definidos sem heroicidades, sem risos, sem direitos; sonhos, filhos de cruzamentos, penetrações, violências, soberanias; sonhos de todos os portos do mundo, de todas as cartas do mundo; de todas as caras do mundo (SALÚSTIO, 1998b, p. 33, 34, 42).

\section{- Painel: O Ambiente}

Cena 1: O Sahel (Dina Salústio, giz pastel sobre papel pardo, com efeitos fauve)

Ao primeiro toque nada acontece: rochas escarpadas, vales profundos, ventos enlouquecidos no princípio dos tempos, mar revolto, praias infindas. Há também o sol. Eterno e impiedoso que nos queima o ventre, a terra e os cascos: os nossos e o das cabras, nossas de todos os dias.

A certeza do deserto nas areias que voam livres pelos caminhos abertos (SALÚSTIO, 1993, p. 24).

\section{Cena 2: A seca (Dina Salústio, serigrafia em madeira)}

Somos um país seco, de seca garantida. (...) 0 crioulo, a partir de Junho, começa a incubar dentro de si um ser ruim, desconfiado, medroso, inseguro. E à medida que os dias passam e os meses entram e saem, os olhos ficam enviezados entre o céu e a terra, os lábios desaparecem nos encovados do rosto, resmungando por tudo e nada sobre a ingratidão as chuvas, a maldição das ilhas, os pecados cometidos. Traído, porque as nuvens maninhas mais uma vez cumpriram o seu destino de negar à terra o consolo da água, o crioulo enraivece-se contra tudo o que o rodeia. Torna-se insuportável de tão intolerante, tão feio, tão desamado.(...)

Eu fujo dos meus patrícios nos meses das águas frustradas. Eu fujo de mim. (...) Somos todos uma ameaça colectiva, de tanta tristeza (SALÚSTIO, 1994, p. 61-2).

\section{Cena 3: A chuva: esperança ou desolação (Vera Duarte, afresco)}

Num céu de um azul indescritível navegam nuvens carregadas de esperança. Pouco abaixo uma terra fissurada por anos de seca, desesperadamente espera 
que as nuvens se precipitem sobre ela abençoando as sementeiras dolorosamente parturientes, as almas ressequidas e as rochas escalabradas. (...) Quando finalmente a esperança sorrir num céu carregado de nuvens e num arrepio da pele mal agasalhada, as águas desabarão violentas e, sem compaixão, arrastarão para o mar profundo tudo o que foi esforço, entrega e devoção, nesta crença irrenunciável e dolorosa da chuva que virá (DUARTE, 2001, p. 84).

\section{Cena 4: A fome (Fátima Bettencourt, carvão sobre papel reciclado)}

Entre porcos e balaios pode muito bem ser a síntese da nossa vidinha na busca difícil da cachupa diária, a luta secular 'dessa outra gente aí, fraca e miúda' no dizer de Saramago.

O Dr. Baltasar dizia com muita graça e fruto do seu agudo sentido de observação que Caixa Económica de pobre em Cabo Verde é o porco. Mas como? (...) nas fomes que assolaram o Arquipélago no passado houve gente que sobreviveu a comer lagartixas (...). Fico a imaginar (...) quantos mais porcos vai ser preciso criar para erguer tantos outros lares (BETTENCOURT, 2001, p.163-4).

\section{Cena 5: A cabra (Fátima Bettencourt, tinta acrílica sobre pedra preta vulcânica)}

Outro dia, na abertura dum Seminário, fiquei surpreendida com algumas coisas que vi e ouvi sobre a nossa fauna e flora e mais ainda com os riscos de desertificação progressiva e irreversível. (...) Quando falamos em desertificação de CaboVerde vem logo à baila o papel destruidor da cabra que, sem ser esquisita, degusta com o mesmo apetite voraz uma erva, um jornal, uma partitura e até mesmo um edital de casamento.

Nessas alturas todos parecem esquecer que sem a cabra provavelmente não teríamos sobrevivido. Qual o ser vivente destas ilhas que simboliza melhor que ela a perseverança, a teimosia e a sobrevivência? (Ibidem, p. 39-41)

\section{- Painel: A Cultura}

Cena 1: A morabeza (Fátima Bettencourt, acrílica sobre madeira)

Enquanto eu apertava a mão do John (...), o rosto simpático na minha frente, pronto para ser amigo, tantos anos longe da morabéza da sua terra,quase esquece o crioulo e as idiossincrazias dos ilhéus, os abraços acompanhados de sonoras palmadas e convites para almoçar um caldo de peixe, uma cachupa, um modje (...) uma morabéza que apesar de nos ser tão cara vai desaparecendo da nossa prática quotidiana (Ibidem, p. 303 e 321).

Cena 2: A culinária identitária _ milho, pratos típicos, fogão tradicional (Orlanda Amarílis, mosaico sobre tela: colagem de ar eia, pedras e sementes de milho)

Chiquinha acabou de arrumar as três pedras para o improvisado fogão quase no meio do quintal. Bostas secas de burro, papéis velhos e alguma lenha, arrumados entre as três pedras de granito, dariam a primeira fogueira para a goiabada. (...)

Do quarto da titia ou de qualquer dos outros, descortinava-se o Pasmatório onde durante um mês se cantavam as ladainhas para a Senhora do Rosário.(...) 
As vozes das mulheres derramavam-se pelas casas da ladeira enquanto os dedos marcavam nas contas do rosário o final de cada ave-maria. O cântico, qual coro de carpideiras, espreguiçava-se pela noite. (...)

Como eu gostava de ir atrás da titia quando ela ia à despensa.(...) A cozinheira ficava à porta e a titia ia dispondo os géneros para o dia. Deitava duas medidas de milho. Uma para cuchir a cachupa, outra para moer para as papas.(...) Um saquito com farinha-de-pau para aloirar com toucinho frito faria também parte da refeição (AMARÍLIS, 1989, p. 95-96).

Cena 3: O crioulo, língua materna, com suas variantes ilhoas (Fátima Bettencourt, litogravura em pedra calcár ea)

Precisam 'beliscar', dizia-me há dias alguém querendo incentivar certo programa radiofónico a ser mais acutilante.

Fiquei a matutar na insólita sugestão. Na verdade se pensarmos bem, beliscão em Cabo Verde tem sentidos vários, nenhum deles o tal a que se referia o meu interlocutor. Na nossa gostosíssima língua mãe, expressão ideal das vivências crioulas, vamos encontrar 'picnic' na zona de Barlavento e 'tchaputi' em Sotavento, ambos mais utilizados para fins amorosos do que punitivos (BETTENCOURT, 2001, p. 81).

Cena 4: A música identitária (Ivone Aída, óleo sobre tela)

Ali, Linda encontrara realmente uma paz interior ao contemplar o horizonte, o oceano vasto e límpido, o céu estrelado e sem nuvens, as noites de lua cheia que a extasiavam, ouvindo Carlos dedilhando no seu violão mornas e coladeiras. Sentiu-se renascer ao ver a luta humilde e resignada contra a estiagem e a fé renovada em cada rosto, sempre alegre. Sentiu-se reviver nos braços de Carlos, dançando e cantando ao som da música típica caboverdeana (RAMOS, 1990, p. $51)$.

Cena 5: A mulher, guardiã e preservadora do patrimônio cultural do Arquipélago (Fátima Bettencourt, acrílico sobre tela com textura)

As brinholas, o cuscus, os chás de erva, os licores da Paula atraíram milhares de nacionais e estrangeiros, mobilizaram as câmaras de TV e até ultrapassaram as fronteiras das Ilhas indo parar à Televisão portuguesa, sei lá mais onde, levando consigo momentos de plena cabo-verdianidade.

Rebuscando receitas originais antigas, vasculhando papéis e memórias envelhecidas mas ainda muito nítidas e desenterrando segredos ciosamente guardados pelas velhas senhoras da Ilha de Santo Antão, a Paula conseguiu recriar sabores e temperos, gestos e medidas considerados já perdidos para sempre (BETTENCOURT, 2001, p. 302).

Cena 6: A representação imagética da ancestralidade: os velhos, a transmissão do patrimônio e o 'Teleolhar' globalizado (Fátima Bettencourt, díptico, tons de acrílica verde e terra sobre tela: Santo Antão e Santiago) 
Santo Antão é entre as nossas ilhas a que mais se orgulha dos feitos dos mais velhos guardando-os com carinho e passando-os a outras gerações (BETTENCOURT, 1992, p. 99).

Uma zona histórica com seus sobrados, varandas de ferro, casinhas de meiaporta onde velhas de cachimbo se sentam para contar estórias aos netos impacientes na hora da televisão que os acaba levando, deixando a velha sozinha a derramar o seu olhar mortiço sobre as agressões que sofre a sua morada (Ibidem, p. 15).

\section{- Painel: Retratos Crioulos}

1. O povo cabo-verdiano (Vera Duarte e Dina Salústio, pintura livre a dedo, cola e anilina sobre papel)

Somos filhos dilectos

De um povo herói do quotidiano (DUARTE, 1993, p. 98)

Esquece-se o deserto, a solidão e a sede, e os homens e as mulheres milagrosamente reinventam ilhas para além do mundo, com as pedras das rochas nuas, o sal da água azul, o sol do céu vermelho, o querer dos desejos queridos.

Quem falou em impotência? (SALÚSTIO, 1993, p. 24)

\section{No mercado (Fátima Bettencourt, aquarela)}

O mercado é uma beleza para os olhos. O colorido de mãos dadas com a abundância, nem sei como, num ecrã como este. Mas Deus é grande e das ribeiras e hortinhas perdidas nos vales recônditos saíram os rubros tomates, o feijão verde, o pimentão estuante de brilho e cor, o milho em todas as suas formas, reduzido a farinha, a xerém e a rolom, o côco, a mandioca, a batata, a couve, os temperos verdes fresquinhos, muita cebola verde e coentros e salsas, um cheirinho bom de terra molhada e fértil subindo até as narinas(...) Para quem entra no mercado como simples turista ou compradora, o cenário assemelha-se a uma aguarela, a beleza é de tirar o fôlego (BETTENCOURT, 2001, p. 33-4)

3. Esmola de Merca (América), velhice e pobreza (Orlanda Amarílis e Ivone Aída, díptico, carvão sobre papel pardo)

O povo fora-se juntando do lado de fora. Aguardava. Não fora preciso avisá-lo. Ainda o vapor não havia alcançado o ilhéu Raso e já ele sabia: a esmola dos patrícios vinha pela Baía dentro. $\mathrm{Na}$ sua maioria eram mulheres velhas, andrajosas, de olhos encovados e cabelo engasgado pelo pó e falta de pente, escondido debaixo do lenço vincado de tanto uso. Parte delas viera arrimada ao seu pau de laranjeira, desde a Ribeira Bota, a arrastar os pés descalços e gretados (AMARÍLIS, 1991, p. 53).

Chegou Sábado o dia das esmolas. Da Ilha da Madeira Fonte de Filipe e Fonte Inês, as velhas começaram a descer para a morada. Ponto de encontro, a calhar. Nha Joana, vinha mais à frente, tinha assumido um ar de sofrimento. Trazia uma saia remendada, pés descalços. O lenço às pintinhas azuis, mal the cobria os cabelos sujos. Na mão, um cestinho de carriço já esburacado e encardido serviria para arrecadar as esmolas. (...) A pouco e pouco as velhas foram formando grupos de seis, sete e até dez pessoas e enfileiravam-se às portas das 
lojas esperando.(...) Algumas traziam crianças pelas mãos, iniciando-as já, nessa vida de peditório e miséria (RAMOS, 1990, p. 64-6).

\section{País real e país virtual (Fátima Bettencourt, pintura digital)}

Um pouco mais perplexa fico quando vejo desenhar-se sob os meus pés dois países: um real e outro virtual. E, mais insólito ainda, em franca competição, sobrando para o cidadão comum uma dúvida atroz: qual é o real e qual é o virtual. Creio até ser esta ambigüidade uma das mais assustadoras sequelas da informática (BETTENCOURT, 2001, p. 541).

\section{Mulher cabo-verdiana}

Primeiro: For ça e evolução (Vera Duarte, acrílica sobre madeira, díptico)

Elas invadem a cidade com o seu coloquiar alegre e barulhento, o sorriso alvo e rijo de mulheres que não hesitam face a nada para poder criar os filhos (DUARTE, 2001, p. 83).

Pelo tempo por que passei deixei gravados os meus sinais d'insurreição, revolta e rebeldia e d'alegria para lá da dor(...)

de jornadas de luta de oitos de março do repto de Rimbaud do no woman no cry da fantástica solidariedade (Ibidem, p. 57-8)

Segundo: Conceição, a Vênus do pó (Maria Margarida Mascarenhas, óleo espatulado sobre tela)

Conceição amava o deserto. Buscava sempre as achadas descampadas para brincar. O Mar nunca. Banhava-se no pó, sentia as pedras e brincava com as nuvens em permanente mutação ao sabor do vento. (...)

Quando as nuvens açuladas pelo vento doido cabriolavam no céu, projectando sombras velozes, Conceição corria desafiando as nuvens, desafiando o vento. (...)

Conceição irrompendo naquela paisagem de sol transparente que crestava a pele, as roupas, o lixo... O pó triturado, farinha solta arrastada pelo vento, mascarando as casas e a palha das coberturas. A poalha nas gentes e nas coisas. A Ilha enfarinhada, crestada como os pães nos cestos de madrugada. (...) Quase todos correndo para o Mar. E Conceição sob o sol virada para a Terra. Fincada no chão das Achadas, decorando as pedras (MASCARENHAS, 1988, p. 14-15).

Terceiro: Prima Antónia, a altivez (Fátima Bettencourt, alto-relevo em massa acrílica sobre tela)

(...) as mulheres foram separadas para que os senhores brancos pudessem escolher as que lhes convinham para as suas casas. Postas em fila foram examinadas minuciosamente até que um dos manda-chuvas parou em frente da 
prima Antónia, tocou-lhe o queixo, passou-lhe a mão pelo longo e sedoso cabelo e comentou apreciador:

_ Você é de boa raça!!!

Āo que prima Antónia, altiva, respondeu:

Com devida atenção e respeito, raça é raça de cabra. Eu sou de boa família. Minha avó era uma branca da Europa, mais branca do que o senhor." (...)

Ela deixou um legado de coragem e inconformismo, um património de dignidade e nobreza que é dever de cada um conservar intacto e passar às próximas gerações (BETTENCOURT, 1994, p. 29-32).

\section{Quarto: Augusta, a Vênus-música (Fátima Bettencourt, acrílica sobre tecido, fauve)}

Toda ela era energia pura, os pés descalços não paravam quietos, com os braços roliços abraçava o próprio busto num visível esforço para se conter. Irradiava dela uma chama que na época eu não soube compreender mas agora não me surpreende que se mantivesse acesa e nítida nas minhas lembranças de muitos anos atrás.(...)

Minha mãe, meio desconfiada de tanta alegria de viver, resmungava contra o conteúdo duvidoso de algumas músicas de sua preferência. Até que um dia ela não apareceu no trabalho e mandou uma prima avisar de que estava passando mal por causa da gravidez. (...) o homem que arranjou levou-a para Santo Antão e pô-la a trabalhar na estrada onde apanhou uma tuberculose. (...) Acabou morrendo, deixando o primeiro filho pois o segundo se fora por conta de uma diarreia ao sol e ao vento das estradas do Porto Novo. A minha mãe tomou conta do garoto e criou. É um dos meus irmãos adoptivos. Vive na Suécia, dedica-se à música nas horas livres, um gosto que certamente apanhou quando boiava no útero materno (Ibidem, p. 34-36. Grifos meus. As músicas eram coladeiras, de ritmo rápido e conteúdo sensual).

\section{Quinto: Mulher anônima (Dina Salústio, carvão sobre papel pardo)}

A noite estava serenamente calma e o calor convidava a estar-se a olhar para as estrelas, preguiçosamente (...). De lá das bandas do cemitério uma voz canta uma morna. Tudo normal se a voz não parecesse sair dos intestinos de algum bicho em vez de uma garganta humana, por muito desafinada que fosse. Era de uma mulher, reconheci com mais cuidado. Aliás, eram as vozes de duas mulheres. A segunda faz coro com obscenidades e a desarmonia, o desleixo transparecido e o despudor agridem os ouvidos. (...) Vêm-se aproximando. E estão bêbadas. (...) Sinto raiva. Agora posso vê-las no arco iluminado pelo candeeiro. Parecem-me jovens. (...) A noite não tinha mais magia. Acho que nem estrelas. (...) vou pensando, enquanto desço as escadas.

E os passos falam vergonha, humilhação e revolta. E pena (SALÚSTIO, 1994, p. 46-7. Grifos meus) $)^{13}$.

\section{Sexto: A vencedora e a oportunidade do grito (Dina Salústio, $\underline{\text { sangüínea }}$ sobre papel)}

- Tens que largar essa maneira de estar, pôr de lado o marasmo que te envolve. Parece até que estás a pedir esmolas à vida - dizia a vencedora.(...)

- Mas se eu não faço mal a ninguém! Se eu nem tenho inimigos!

13 Canto feminino em coro, típico da morna tradicional. 
Ah! Aí é que está _ quase gritou a outra _ tens que incomodar, mostrar que existes, perturbar, brigar com o mundo e contigo. Sobretudo contigo. É um treino que atrai bons fluidos. Os outros, vendo a coragem com que te desafias a ti mesma, respeitam-te e temem-te. (...)

Claro que não quero continuar neste vegetar e, para que saibas, luto, esforçome, rezo, (...) peço a Deus...

Pedes a Deus? Idiota! Tens é que discutir com Ele. Enfrenta-O como mulher. Mostra-lhe as tuas razões. Grita se for preciso. Ele é que te pôs aqui, não é? Pois que assuma a sua parte da responsabilidade (Ibidem, p. 7-8).

\section{Retratos do Cotidiano}

Primeiro: A violência (Dina Salústio, sangüínea e nanquim sobre papel)

Mulheres amachucadas. Homens maltratados. Crianças espancadas, de cabeças e mãos rebentadas, sorrisos desfeitos e olhos vazados.

Éramos um povo de brandos costumes. (...)

$\mathrm{Na}$ normalidade do quotidiano a violências ganha espaço e afirma-se. Alguns defendem que a nossa dureza vem das rochas, da fome e das secas. Outros encaixam-na na escravatura (Ibidem, p. 44-45).

Segundo: A violência contra a mulher (Maria Margarida Mascarenhas, sangüínea sobre tecido)

Levou-a para casa à força de pancada e brutalidade. Cheirava a bebida! (...) Como suportara tantos insultos? Refugiou-se em casa da comadre, mas ele entrou e arrastou-a para fora sem fazer caso aos rogos da comadre. Espancou-a mesmo depois de terem entrado em casa. Os filhos choravam e armou-se um berreiro... o pior de tudo foi a paulada no ouvido. Ainda continuava a ir fazer tratamentos ao Hospital (MASCARENHAS, 1988, p. 20).

Terceiro: Vivências crioulas ou Cabo Verde no mundo, Cabo Verde e o mundo (Fátima Bettencourt, mosaico de cacos de vidro coloridos)

Pulverizado pelo mundo, o povo destas ilhas tem levado a cada cantinho deste planeta o seu toque de criatividade, a marca do engenho nascido da sua vivência em condições quase impossíveis, a sua malícia e a sua graça também frutos duma vida inteira em equilíbrio precário entre a desistência e a teimosia, esta sempre vencedora. (...)

Saído das Fajãs e das Achadas ignoradas, galga o mundo (...), nunca desiste de passar aos outros a sua vivência crioula, o seu grogue, o seu tabaco puído, a sua cachupa, o seu violão, a sua língua. (...)

As estórias dessas vivências, desses encontros, desses choques, constituem um mosaico rico e colorido, pleno de vida e calor, e mereciam ser compiladas e contadas para glória do homem anónimo, a lenda viva que é o cabo-verdiano na diáspora (BETTENCOURT, 2001, p. 57-8. Grifos meus).

\section{- $\quad$ Ponto Final}

Do que pudemos depreender da "leitura em diagonal" que essas "mulheres sem medo" (como se define Fátima Bettencourt) fazem do mundo cabo-verdiano, a mulher é força atuante não apenas como mão-de-obra valiosa nos campos, construções e 
trabalhos domésticos, mas também na manutenção da família e, do ponto de vista que aqui mais nos interessa destacar, no resgate, na preservação e na transformação do patrimônio cultural crioulo.

$\mathrm{Na}$ cultura cabo-verdiana alicerçada na mestiçagem, o encontro das práticas africanas com a religião católica mantém-se pela ação feminina, que conservou os costumes do batizado, da boda, do culto ao padrinho e à madrinha, junto às superstições e práticas mágicas, ao recurso às botadeiras de sorte. A língua nacional, o crioulo, bem como as práticas e comportamentos são transmitidos pelas mães às crianças. Por via feminina são preservados o artesanato (rendas, bordados, cestos, artefatos de barro), a medicina tradicional (curandeirismo, parteiras, com seu cachimbo, remédios caseiros, rezas e estórias), o fabrico do sabão de purgueira, a culinária com função identitária (confecção da cachupa, do pirão, do xerém), e ainda o pilão ${ }^{14}$ e a tabanca ${ }^{15}$.

A manutenção da tradição oral dos contos fantásticos da boca di tardi, dos coros femininos que atuam nas cerimônias fúnebres ${ }^{16}$ e nas guisas (comunicação da morte), da morna, do batuque, das finaçons e cantigas de trabalho entoadas (e muitas vezes compostas) pelas cantadeiras tradicionais, como Na Bibina Cabral, Na Nasia Gomi, Na Gida Mendi, Ana Procópio ${ }^{17}$, consagram, enfim, a mulher crioula como guardiã da memória e grande transmissora da cultura.

A morna tradicional ${ }^{18}$, manifestação musical preservada pela mulher do povo, canta o trabalho na lavoura, a lavagem de roupa, o carregamento de mercadorias; a morna contemporânea, cuja musa é a Cesária Évora dos pés descalços, canta o amor (crecheu), a saudade, os povos irmãos africanos, o Caminho para S. Tomé.

As cantadeiras das ilhas, ao lado das escritoras que ora estudamos, criam e /ou perpetuam as manifestações culturais cabo-verdianas. Movendo-se entre o cantar e o contar, confundindo-se com a Terra, vão tecendo e semeando o passado e o futuro.

Certamente alguns podem argumentar que o seu olhar já foi capturado por mulheres esplendorosas, fortes, belas, musicais, sensuais, guerrilheiras da vida que se

14 Quando as mulheres pilam o milho, símbolo da identidade nacional, para preparar o xerém.

15 Executada por mulheres que tocam percussão em panos, bolsas e garrafas de plástico, batendo nas coxas.

16 As mulheres, além de terem a missão do choro, abrem o cortejo fúnebre e cantam os requiens.

17 Cf. a obra de Tomé Varela da Silva, importante no registro das tradições orais transmitidas por via feminina; sobre Ana Procópio, Claridade, 9.

18 Originada através do canto de uma solista acompanhado por um coro feminino, segundo Vasco Martins, 1988. P. 18-19. 
saltam dos textos literários de António Aurélio Gonçalves, Ovídio Martins, Gabriel Mariano (e tantos outros que figuram no cânone crioulo) ou das telas de Kiki Lima. Só que, em moto crescente a partir dos anos 80 , as mulheres cabo-verdianas agora recortam a realidade segundo as suas vivências cotidianas, assumindo o seu protagonismo, a diagonal do seu olhar e a sua própria voz: "agora estão mais alegres, mais espontâneas, mais soltas e seguras" (BETTENCOURT, 2001, p. 237.)

A elas, a nossa homenagem.

\section{Referências bibliográficas}

ABDALA Jr., Benjamin et alii. Literatura e história: três vozes de expressão portuguesa. Porto Alegre: UFRGS, 1999.

Editorial, 2003.

De vôs e ilhas: literatura e comunitarismos. Cotia: Ateliê

ALMADA, José Luís Hopffer. O papel do milho na simbolização da identidade cultural do cabo-verdiano. In: Cabo Verde: insularidade e Literatura. Paris: Karthala, 1998. p.6380.

ALMEIDA, Sara. Depois telefono. Novela. Praia: Instituto Caboverdiano do Livro, 1993.

AMARÍLIS, Orlanda. Ilhéu dos pássaros. Lisboa: Plátano, 1983. . . A casa dos mastros. Linda-a-Velha: ALAC, 1989.

Cais do Sodré té Salamansa. Linda-a-Velha: ALAC, 1991.

BETTENCOURT, Fátima. Semear em pó: contos. Praia: Instituto Caboverdiano do Livro e do Disco, 1994.

Um certo olhar. Praia: Instituto da Biblioteca Nacional, 2001.

CARREIRA, António. Cabo Verde: classes sociais, estrutura familiar, migrações. Lisboa: Ulmeiro, 1977.

DIAS, Maria Odila Leite da Silva. Novas subjetividades na pesquisa histórica feminista: uma hermenêutica das diferenças. In: Estudos feministas. UFRJ/CIEC, $2^{0}$ semestre, 1994, p. 373382.

DUARTE, Dulce Almada. A mulher caboverdiana, principal transmissora de cultura da nossa sociedade. . In: Mujer. Praia, n. 1, março 1982, p. 10-11.

DUARTE, Vera. Amanhã amadrugada. Praia: Instituto Caboverdiano do Livro e do Disco, 1993.

O Arquipélago da paixão. Mindelo: Artiletra, 2001. Prefácio de Simone Caputo Gomes.

FERREIRA, Manuel. A a ventura crioula. Lisboa: Plátano, 1885.

GOMES, Irineu. Juventude e adolescência, mulher e sociedade, psicopatias e desequilíbrios emocionais. Praia: Instituto Caboverdiano do Livro, 1986.

GOMES, Simone Caputo. Uma recuperação de raiz. Cabo Verde na obra de Daniel Filipe. Praia: Instituto Caboverdiano do Livro e do Disco, 1993.

- A poesia africana de língua portuguesa em voz de mulher. In: Cadernos de Letras da UFF. A mulher na Literatura. Niterói, n. 8, 1993, p. 61-72.

Cabo Verde: rosto e trabalho femininos na evolução da cultura e da Literatura. In: O rosto feminino da expansão portuguesa I. Actas do Congresso Internacional. Lisboa: Comissão para a Igualdade e Para os Direitos das Mulheres, v. II, 1995, p. 275-340.

. Feminino e poesia africana de língua portuguesa. In: Mulher e Literatura, Anais do V Seminário Nacional. Natal: UFRN/ Editora Universitária, 1995, p. 333-340.

. Cabo Verde: mulher, cultura, Literatura. In: Revista Pré-Textos. Praia:

Asssociação de Escritores Cabo-verdianos, dezembro 1998, p. 27-35. 
Cabo Verde: A Literatura como expressão de cultura. In: Mar Além. Revista de Cultura e Literatura dos Países Africanos de Língua Oficial Portuguesa, Lisboa, p. 23-25, 1999.

A louca de Serrano, de Dina Salústio. In: Metamorfoses, Revista da Cátedra Jorge de Sena para Estudos Literários Luso-afro-brasileiros/UFRJ. Lisboa: Cosmos, 2000, p. $277-281$.

Mulher com paisagem ao fundo: Dina Salústio apresenta Cabo Verde. In. África e Brasil: letras em laços. Organização de SEPÚLVEDA, Maria do Carmo \& SALGADO, Maria Teresa. Rio de Janeiro: Atlântica, 2000, p. 113-132. 2.ed: São Caetano do Sul: Yendis, 2006, v. 1, p. 97-117.

Ainda e sobretudo a paixão. In: Contatos e ressonâncias: literaturas africanas de língua portuguesa. Organização de LEÃO, Ângela Vaz. Belo Horizonte: PUC Minas, 2003, p. 407-426.

Óleo sobre tela: mulher com paisagem ao fundo ( a prosa literária de autoria feminina em Cabo Verde). In: Refazendo nós: ensaios sobre mulher e literatura. Organização de BRANDÃO, Izabel \& MUZART, Zahidé. Florianópolis: Mulheres-EDUNISC, 2003, p. 317326.

Echoes of Cape Verdean Identity: Literature and Music in the Archipelago. In: Cape Verde: language, literature \& music. Organização de LEITE, Ana Mafalda. Dartmouth: Portuguese Literary \& Cultural Studies, University of Massachusetts Dartmouth, n. 8, 2003, p. $265-285$.

Lição de crônica: Um certo olhar de Fátima Bettencourt sobre o mundo caboverdiano. In: Cape Verde: language, literature \& music. Organização de LEITE, Ana Mafalda. Dartmouth: Portuguese Literary \& Cultural Studies, University of Massachusetts Dartmouth, n. 8, 2003, p. 457-461.

Preces e súplicas ou os cânticos da desesperança. In: Metamorfoses. LisboaUFRJ: Caminho-Cátedra Jorge de Sena para Estudos Literários Afro-luso-brasileiros, 2006. A poesia em Cabo Verde: um trajeto identitário. In: LUCCHESI, Marco (org). Poesia Sempre, v. 23. Rio de Janeiro: Biblioteca nacional, 2006,p. 263-273.

Um certo olhar de Fátima Bettencourt sobre Cabo Verde. In: Via Atlântica (USP), v. 10, p. 101-116, 2007.

Nhô Baltas e o Brasil: a proximidade de dois mundos irmãos. In: Latitudes: cahiers lusophones, Paris: v. 30, 2007, p. 45-48.

$\mathrm{O}$ texto literário de autoria feminina escreve e inscreve a mulher $\mathrm{e}(\mathrm{m})$ Cabo Verde. In: MATA, Inocência; PADILHA, Laura Cavalcante. (Org.). A mulher em Áffica: vozes de uma margem sempre presente. 1 ed. Lisboa: Colibri, 2007, v. 1, p. 535-558.

HOLLANDA, Heloísa Buarque de (org). Tendências e impasses: feminismo como crítica da cultura. Rio de Janeiro: Rocco, 1994.

GOVERNO DE CABO VERDE. Análise de situação: Criança e Mulher em Cabo Verde 1998. Praia: Programa de Cooperação 2000-2004 do Governo de Cabo Verde/ Fundo das Nações Unidas para a Infância, 1999.

LIMA, Aristides R. Reforma política em Cabo Verde: do paternalismo à modernização do Estado. Praia: Grafedito, 1991.

LOPES FILHO, João. Retalhos do quotidiano. Lisboa: Caminho, 1995.

MACEDO, Tania. Estas mulheres cheias de prosa: a narrativa feminina na África de língua oficial portuguesa. In: Contatos e ressonâncias: literaturas africanas de língua portuguesa. Organização de LEÃO, Ângela Vaz Belo Horizonte: PUC Minas, 2003, p.155-168.

MARIANO, Gabriel. Cultura caboverdiana: ensaios. Lisboa: Vega, 1991.

MARTINHO, Ana Maria M. Contos de África: escritos por mulheres. Évora: Pendor, 1994.

MARTINS, Vasco. A música tradicional cabo-verdiana: a morna. Praia: ICLD, 1988. V.1.

MASCARENHAS, Maria Margarida. ...Levedando a ilha: contos. Linda-a-Velha: ALAC, 1988.

MATA, Inocência. As vozes literárias femininas na Literatura Africana: passado e presente. In: $O$ rosto feminino da expansão portuguesa. Actas. Lisboa: Comissão para a Igualdade e para os Direitos das Mulheres, v.2, 1995, p. 251-258.

OSÓRIO, Victor Adolfo de Pinto. Vencendo barreiras. Praia: Instituto da Condição Feminina, 1999.

PADILHA, Laura Cavalcante. Entre voz e letra: o lugar da ancestralidade na ficção angolana do século XX Niterói: EDUFF, 1995.

PEDRO, Joana Maria \& GROSSI, Miriam Pillar. Masculino, feminino e neutro. Florianópolis: Mulheres, 1998. 
RAMOS, Ivone Aída Fernandes. Vidas vividas. Mindelo: OMCV, 1990.

RAMALHO, Christina (org). Literatura e feminismo: propostas teóricas e reflexões críticas. Rio de Janeiro: Elo, 1999. Prefácio de Simone Caputo Gomes.

SALÚSTIO, Dina. "Cantar ... ou chorar apenas”. Revue noire. Cabo Verde. Paris, n. 10. set-nov. 1993, p. 24-25.

. Mornas eram as noites. Praia: Instituto Caboverdiano do Livro e do Disco, 1994.

Entrevista (a Simone Caputo Gomes). Praia, novembro de 1994.

A louca de Serrano. Praia: Spleen, 1998a.

Insularidade na Literatura Cabo-verdiana. In: abo Verde: Insularidade e Literatura. Paris: Karthala, 1998b, p. 33-44.

Fragmento de romance inédito. In: Metamorfoses. Rio de Janeiro: Cátedra Jorge de Sena/UFRJ v. 2, 2001, p. 73-78.

SARAMAGO, José. “Caboverdiando”. Jornal de Letras. Lisboa, n. 731, 14 de outubro de 1998, p. 28-29. 